\title{
The ILO's Endeavour to Eliminate Child Labour Worldwide: A Discourse on Legitimacy and Standards Fit for Purpose
}

\author{
Alexis Foua1, Wilson Diriwari² \\ ${ }^{1}$ Lecturer in Law at Arden University, London, United Kingdom \\ ${ }^{2}$ Solicitor in England and Wales, London, United Kingdom \\ Email: Afoua@arden.ac.uk,wilson@wsolicitors.co.uk
}

How to cite this paper: Foua, A., \& Diriwari, W. (2019). The ILO's Endeavour to Eliminate Child Labour Worldwide: A Discourse on Legitimacy and Standards Fit for Purpose. Beijing Law Review, 10, 1262-1281. https://doi.org/10.4236/blr.2019.105068

Received: October 29, 2019

Accepted: December 7, 2019

Published: December 10, 2019

Copyright $\odot 2019$ by author(s) and Scientific Research Publishing Inc. This work is licensed under the Creative Commons Attribution International License (CC BY 4.0).

http://creativecommons.org/licenses/by/4.0/

\begin{abstract}
The article examines the extent to which International Labour standards (ILS) have contributed to combating child labour. Child labour is regarded as an impediment to children's development and their human rights. The ILO's endeavour to improve labour relations and eradicate child labour globally has seen the organisation engaged in adopting Conventions and Recommendations focusing on current critical issues in the labour environment. The idea that the International labour Organisation is a necessity which the world has been waiting for years (Thomas, 1921: p. 5, 22) is underpinned by the working mechanisms that are well accepted among member states. More significantly, the optimism of the founders and their desire to thrive were the driving forces necessary to put the ILO on the track to longevity. Hence, the article evaluates the working mechanisms of the organisation which facilitate the materialisation of its approaches to various labour issues. The approach taken is a textual analysis and justification of the International Labour Standards (ILS). The article concludes that the ILO has the legitimacy to set international labour standards and that its standards are fit for purpose. Indeed in the light of its focus, its working mechanism, and its efficient approach to labour issues, the ILO cannot be denied the status of "most adequate institution" in addressing child labour issues with a view to eradicating the phenomenon worldwide.
\end{abstract}

\section{Keywords}

International Labour Organisation, Child Labour, International Labour Standards, Labour Relations, Child Development, Human Rights

\section{Introduction}

The International Labour Organisation (ILO) was established in 1919 as part of 
the Treaty of Versailles that ended the First World War. Legitimacy has never been an issue in the debate about the ILO's standards-setting role. Instead, the view that the ILO lacks the capability to address challenging labour issues in the international arena required a meticulous analysis and rebuttal (Douglas, Ferguson and Klett, 2004: p. 273, 299). In fact, the ILO's policy making has impressed many scholars (Lorenz, 2002: p. 101, 112). There is ample evidence from different sectors to support the assertion that ILO's role is justified and defensible. The ILO's method of governance (Rodgers, Lee, Swepston, Van Daele, 2010), its uniqueness in applying the tripartite mechanism, its endeavour to promote social justice, its eagerness to refocus international competition, and its resolution to establish a permanent social dialogue are qualities that not only strengthen its legitimacy, but also defeat all attempts to portray the organisation as incompetent. All these topics have in common the promotion and protection of human rights in labour relations. The ILO's role in addressing child labour in a broader spectrum is as notable as its targeted efforts to eliminate the worst forms of child labour through Convention No. 182.

Additionally, the supervisory system, regarded as one of the key working tools of the ILO, is of great service to the organisation's determination to effectively implement its standards (Nielsen, 1995: p. 129, 150). International labour standards are backed by a supervisory system of the ILO that is unique at international level. The regular system of supervision helps to ensure that countries implement the Conventions they ratify and is a mechanism whereby the ILO regularly examines the application of standards in member states and points out areas where they could be better applied. In this sense, the combat against child labour was well echoed in most members states.

\section{The Defensible Standards-Setting Role: A Justification}

In the justification of ILO's standards setting role, it is worth noting that the tripartite consultation which constitutes one of the core attribute, refers to a process whereby workers, employers and governments contribute to the development of labour standards and the protection of worker rights through voluntary interaction and dialogue (Simpson, 1994: p. 40, 45). The International Labour Organisation is the first and only tripartite U.N. agency that provides for the full participation of government, employer, and worker representatives. This tripartite structure makes the ILO a unique forum in which governments and social partners in the economies of the member states can freely and openly debate and elaborate labour standards and policies (Charnovitz, 2000: p. 147, 184). His mechanism of the ILO was a revolutionary break with the state-centric international order of the early twentieth century (Helfer, 2006: p. 649, 726). From its inception, the ILO's founders were committed to the tripartite structure. Article 3 (1) of the Constitution provides that the ILO General Conference was to have four representatives from member states, two of them representing the government, one representing employers, and one representing workers. More significantly, the ILO has developed three instruments that explicitly promote tripar- 
tism. These instruments are recommendation 113 (1960), ${ }^{1}$ Convection No. 144 (1976), ${ }^{2}$ and Recommendation 152 (1976). ${ }^{3}$ Lorenz is right to think that the tripartite structure is an important historical inheritance of the ILO.

The tripartite structure did not come about by accident, and has since been implemented in many industrial democracies to provide a viable and flexible social contract in those societies (Lorenz, 2002: p. 101, 112; Melanson, 1979: p. 43, 61) observes that 'the founders of the ILO presumed that this unique structure could best reflect the complex pattern of conflict and consensus that characterizes production relations within the industrial democracies.'

Tripartism has made the ILO the most open organisation (La Rosa and Duplessis, 2001) the most representative organisation, and the first international institution in history that brings together workers, employers, and Governments (Beguin, 1959: p. 410, 448). For these reasons, it is a sui generis organisation the like of which had never existed before (Meeker, 1923: p. 206, 210). Even the Governing Body of the ILO is also a tripartite organ; it consists of 56 people, 28 of whom represent governments, 14 employers, and 14 workers. ${ }^{4}$

Moreover, the principle of tripartism is also applied in several departments of the Governing Body, such as the Committee on Standing Orders and International Labour Standards and the Committee on Freedom of Association. It is also evident in the operation of ILO instruments at the national level and supervisory procedures such as the Conference Committee on Application of Standards (Rubin, Kalula, \& Hepple, 2005). As observed above, International Labour Standards have a unique tripartite characteristic that enhances their reception in national law.

\section{Standards Fit for Purpose}

Determining hazardous child labour might appear to be an obvious and straightforward process. However, the ongoing debate on relativist approaches

${ }^{1}$ The Tripartite Consultation (Industrial and National Levels) Recommendation, 1960 (No. 113) (Recommendation 113) was the first ILO instrument to expand upon the concept of tripartism. It essentially proposes that domestic labour relations systems promote effective consultation and cooperation between public authorities and employers' and workers' organizations. See Brian W. Burkett, "Reflections on Tripartism and Labour Law Reform" (2005) 12 Canadian Labour and Employment Law Journal 261, 290.

${ }^{2}$ The Tripartite Consultation (International Labour Standards) Convention, 1976 (No. 144) requires ratifying states to implement procedures to facilitate national tripartite consultations. However, Convention 144 is limited to matters respecting the ILO; it relates to the development, implementation, and review of international labour standards based on a tripartite model at the national level See Brian W. Burkett, "Reflections on Tripartism and Labour Law Reform" (2005) 12 Canadian Labour and Employment Law Journal 261. 290.

${ }^{3}$ The Tripartite Consultation (Activities ofthe International Labour Organisation) Recommendation, 1976 (Ao. 152) (Recommendation 152) elaborates on Convention 144. It proposes the use of tripartite consultation in the preparation and implementation of legislative or other measures designed to give effect to ILO conventions and recommendations, and in dealing with questions arising out of reports to be made under Article 19 of the ILO Constitution, which sets out the procedural steps required to adopt proposed conventions or recommendations. See Brian W. Burkett, "Reflections on Tripartism and Labour Law Reform” (2005) 12 Canadian Labour and Employment Law Journal 261. 290.

${ }^{4}$ Sec. 1 Article 7 of the ILO Constitution. 
to the issue remains a major obstacle to an attempt to agree upon specific activities deemed hazardous for children. Meanwhile in compliance with the ILO Conventions, states have to determine the list of activities regarded as hazardous child labour. The tripartite consultation process for determining hazardous child labour is rooted in the fundamental tenets of the ILO and is a reflection of its long history and commitment to social justice through cooperation between workers, employers, and governments.

The step-by-step guide for facilitators, provided by the ILO for the elimination of hazardous child labour, clearly states that a government must take the lead by naming a person or unit to oversee the determination Process. This is usually someone or some unit within the Ministry in charge of labour and is referred to as the competent authority. Because determination of child labour is an obligation on the government as a ratifying state, it cannot delegate this vital function to an outside body. While the government necessarily leads the process of determining hazardous child labour, the representative bodies of workers and employers must be involved because they are expected to be familiar with the needs and perspectives of the parties they represent. By sitting together at the same table, the three parties can work out solutions or compromises that are most likely to be practical and actually adopted by their constituents than if either were to be there alone or if they were not present at all (ILO, 2012).

The ILO has also impacted the labour environment positively in most developing countries. Etukudo writes that In the 1950s and 1960s, when the majority of African countries achieved independence, they were naturally keen to work with the ILO, but only rarely had national employers' organizations in place. The ILO encouraged the establishment or reactivation of these organizations so that there would be full, tripartite representation in all dealings with the ILO. African employers' organizations make a valuable contribution today to national development beyond their undisputed role in wealth creation. Etukudo rightly observes that the ILO's efforts were founded on the belief that the only way to wage a successful war against poverty and social injustice was through concerted action agreed upon and implemented by employers, workers, and governments (Etukudo, 1991: p. 113). The ILO's engagement on the path of social justice and the promotion of international completion constitute a significant element in the combat aga9nt child labour.

Rephrasing the definition of social justice developed by the British Commission on Social Justice, Christopher rightly emphasises that:

Social justice can be defined in terms of a hierarchy of four ideas. First, that the foundation of a free society is the equal worth of all citizens, expressed most basically in political and civil liberties, equal rights before the law and so on. Second, the argument that everyone is entitled, as a right of citizenship, to be able to meet their basic needs for income, shelter and other necessities. Third, self-respect and equal citizenship demand more than the meeting of basic needs: they demand opportunities and life chances. Finally, we must recognise that although not all inequalities are unjust ..., unjust inequalities should be reduced 
and where possible eliminated (Merret, 2004: p. 103).

Although some scholars perceive social justice as a vague and ill-defined ethical concept (Jancauskas, 1959: p. 34, 50), the core of the values encapsulated in the definitions generally provided is fit for the purpose of establishing stable and peaceful social structures. The founders of the ILO had a keen appreciation of the importance of social justice in securing peace, against a background of exploitation of workers in industrial and industrialising nations. The preamble of the ILO Constitution underscores the necessity of social justice for the establishment of universal and lasting peace. ${ }^{5}$ In the early days, the founders of the ILO had committed themselves to working for social justice as their assessment of the past and their mandate for future, a notion reiterated by Juan Somavia. ${ }^{6}$

The ideal of social justice could have been a misnomer had the ILO failed to create the appropriate institutional framework for its realisation. According to Maupin, tripartism was the institutional expression of the ILO's reformist vision of social justice in that it allows free confrontation and reconciliation of the respective interests of genuine worker and employer representatives with the active involvement of governments (Maupin, 2009: p. 823, 852). In recent years, ILO member states have committed themselves to achieving progress on social justice in the context of globalisation. This commitment echoes the primary goal of the ILO founders. On 10 June 2008 the International Labour Organisation unanimously adopted the ILO Declaration on Social Justice for Fair Globalization. ${ }^{7}$ The Declaration expresses the contemporary vision of the ILO's mandate in the era of globalisation.

The 2008 Declaration builds on the Philadelphia Declaration of 1944 and the Declaration on Fundamental Principles and Rights at Work of 1998. After 90 years of existence of the ILO, social justice remains a deeply-rooted value for the organisation; although the world in which it is to be carried out has profoundly changed in recent years, the mission of the ILO to promote social justice remains unchanged (Hansenne, 1994: p. 3).

The pursuit for social justice as a core mission of the ILO is one of the main arguments that support its standards-setting role. The justification of this mission is an attempt to corroborate its legitimacy in a context where many voices seek to dismiss the ILO as an organisation fit for that purpose. The experience of applying the core principles of social justice has proven beneficial in develop${ }^{5}$ The preamble of the ILO Constitution stipulates that "universal and lasting peace can be established only if it is based on social justice."

${ }^{6}$ Juan Somavia, Director-General of the International Labour Organisation, 1999-2012.

${ }^{7}$ The declaration adopted by the International Labour Conference at its Ninety-seventh Session, Geneva, on 10 June 2008 is regarded as a landmark declaration in that it is a powerful reaffirmation of core ILO values. It is the outcome of tripartite consultations that started in the wake of the Report of the World Commission on the Social Dimension of Globalization. By adopting this text, the representatives of governments, employers', and workers' organizations from 182 member States emphasize the key role of the tripartite Organization in helping to achieve progress and social justice in the context of globalization. See ILO,

http://www.ilo.org/global/meetings-and-events/campaigns/voices-on-social-justice/WCMS_099766/ lang--en/index.htm accessed 28 September 2019. 
ment planning and the post-apartheid urban reconstruction of South Africa.

The experience of applying social justice became evident with the advent of post-apartheid national governance. A number of policy frameworks aimed at planning and funding strategies for the reconstruction of some cities and delivering basic needs to the poor have emerged. Convinced that the important aspect of the impact of apartheid on urban living was "fragmentation "that led to inequality and lack of development in many parts of the cities, South African local government representatives opted for social justice, which is emerging increasingly from their distributive choices. Driven by this salient political motivation to undo apartheid's legacies by rectifying an urban geography that hampers good urban planning, they succeeded in creating Tygerberg, ${ }^{8}$ a city that serves as an exemplary post-apartheid local government construction project (Visser, 2001: p. 1673, 1699).

The South African experience in implementing social justice is crucial in justifying the ILO mission because apartheid is among the most brutal examples of social injustice in humanity's recent history. The underlying consensus in decision-making processes has proven how social justice can bring about sustainable development, economic growth, and prosperity (Specht, Kapur, Rajagopal, David, \& Trubek, 2003: p. 849, 871). From the specific perspective of ILO's mission to promote social justice, it must be understood that the exercise of social justice in employment not only leads to the social well-being of workers but also facilitates the relations between the parties involved in the process (Stiglitz, 2002: p. 9, 29)

At the inception of the ILO, the founders had an acute understanding of the world's economic interdependence and the need for cooperation to obtain similarity of working conditions in countries competing in the same markets. ${ }^{9}$ Albert Thomas emphasised the ILO's drive to dissipate the ever-recurring fear of international competition that threatened the existence of various isolated attempts at reform (Thomas, 1921: p. 5, 22).

Thomas and the ILO heartily adopted the objective of preventing states with poor social standards from gaining a competitive advantage over states with higher ones by establishing international minimum standards that would became paramount (Wisskirchen, 2005: p. 253). International agreements in the field of labour standards would help prevent international competition's being used as an actual or convenient reason to limit workers' rights, and would constitute a code of fair competition among employers and among States. ${ }^{10}$ The idea of fair competition is clearly expressed in the ILO Constitution: "Whereas also,

${ }^{8}$ The City of Tygerberg, located in the Cape Metropolitan Area constitutes the restructured remnants of 16 former apartheid-eralocal governments, service areas, and management organisations brought about by the highly controversial amalgamation of South African cities in 1994-95. See Gustav Visser, 2001 "Social Justice, Integrated Development Planning and Post-Apartheid Urban Reconstruction”, 38 Urban Studies1673, 1699.

${ }^{9}$ ILO, http://www.ilo.org/dyn/normlex/en/f?p=1000:1:0::NO::: accessed 28 September 2019.

${ }^{10}$ ILO, "International Labour Law" at

http://actrav.itcilo.org/actrav-english/telearn/global/ilo/law/lablaw.htm accessed 28 September 2019. 
the failure of any nation to adopt humane conditions of labour is an obstacle in the way of other nations which desire to improve the conditions in their own countries." 11

It can be argued that ILO standards in the current global context are fit for purpose. Indeed the ILO is best understood through the nature of its standards. Wisskirchen writes that: “The ILO's methods of work and the practical results thereof are not well known, notably the content of ILO's numerous International Labour Standards even inside the member States which have ratified them." (Thomas, 1921: p. 5, 22). International labour standards are primarily tools for governments which, in consultation with employers and workers, seek to draft and implement labour law and social policy in conformity with internationally-accepted standards. For many states, this process begins with a decision to consider ratifying an ILO convention.

\section{Understanding the ILO's Approaches to Labour Issues}

The lack of knowledge about the ILO itself has often allowed some scholars to underestimate the significance of the organisation in the global community. Lorenz writes that "I do not know whether I understand why we do not give much attention to the ILO. I think many people are not aware of it" (Lorenz, 2002: p. 102, 112). He continued, expressing surprise that the National Council Research did not mention the ILO in its project to study international labour standards. ${ }^{12}$ Such lack of knowledge or understanding does not facilitate attempts to justify the standards-setting role of the ILO on the world stage. The standards-setting role of the organisation is highly justifiable on the basis of the values embedded in those standards. The International Labour Standards (ILS) are characterised by two features: in the first place, they are universal, as they are intended to be applied in all ILO member states; secondly and a counterweight, they possess certain flexibility; flexibility of standards is the price of universality. ${ }^{13}$

The ILS cover a wide range of subject matter of labour law and social policy. Since the foundation of the ILO in 1919, ILS content has broadened both in

${ }^{11}$ Third preambular paragraph of the ILO Constitution.

${ }^{12}$ As an historian, Ed Lorenz could not understand why the ILO is not given much attention. For him, the ILO's role is so crucial in the world that he urges not only American lawmakers but also all stakeholders around the globe to devote more attention to the organisation. See Ed Lorenz, "Bringing Law to Globalization through ILO Conventions: A Labor Perspective on the Core Labor Standards" (2002) 11 Michigan State University-Detroit College of Law's Journal of International Law 101, 112.

${ }^{13}$ The concept of universality goes beyond the question of the number of states that are members of the organisation. Paramount in that concept is the idea that the aims and purposes of the ILO and the actions that it takes must correspond with the needs of all peoples throughout the world, whatever social or economic regimes might exist in different countries. The principle of universality also means that the functioning of the ILO was not designed solely to fit any given social system or to impose a pattern of social structure to be applied uniformly; instead, it must maintain its purpose to help governments and people of all countries to develop specific solutions to the labour problems that exist in their own particular circumstances. In fact, the activities of the organisation are required to adapt themselves to all possible social forms in those nations that have voluntarily accepted the aims set forth in its Constitution. Its Constitution provides more than adequate scope for such adaptation. See ILO: "Record of Proceedings, International Labour Conference, 37th session" (ILO, Geneva 1954) 436. 
fields and persons covered and the framework in which matters are treated (Valticos \& Von Potobsky, 2005: p. 20). In the first 40 years of their existence, the ILS concentrated on developing and enforcing international labour standards that regulate working conditions, such as working age, working hours, wages, etc (Nghia, 2010: PhD thesis, Brunel University).

On the path to decent work, the ILS are first and foremost about the development of people as human beings. From a functionalist perspective, the need to achieve the goal of decent work in a globalised economy has become crucial. The world community's response to the rising challenges her been to develop international legal instruments on trade, finance, the environment, human rights, and labour. The ILO contributes to this goal by devising and promoting international labour standards aimed at making sure that economic growth and development are accompanied by the creation of decent work. ${ }^{14}$ The pertinence and the impact of such efforts on the worldwide labour environment cannot be ignored or minimised.

The ILO excels in setting International legal frameworks on social standards. The significance of these standards is underpinned by the fact that the international legal framework ensures a level of playing field in the global economy. It is crucial in that it helps governments and employers to avoid the temptation of lowering labour standards in the belief that it could give them greater comparative advantage in international trade. International labour standards are often perceived as entailing significant cost and thus hindering economic development. However, growing body of research indicates that compliance with international labour standards often results in improvement in productivity and economic performance. ${ }^{15}$

In addition to its conventions, the ILO has adopted a number of recommendations. A recommendation does not create obligations but rather provides guidelines for action in some particular area ${ }^{16}$ Recommendations are officially communicated to every member state of the ILO, which is expected to bring them before the authorities within whose competence the matter lies for enactment of legislation or other actions. ${ }^{17}$ ILO recommendations are considered soft law, whereas ILO Conventions are considered hard law (Kuruvilla \& Verma, 2006: p. 13, 51). By May 2010, the ILO had adopted 199 Recommendations in a wide range of areas. It is also worth noting the contribution of the ILO Codes of Practice in guiding the general trend for the betterment of workers worldwide. ${ }^{18}$

${ }^{14}$ http://www.ilo.org/global/standards/introduction-to-international-labour-standards/the-benefits-o f-international-labour-standards/lang--en/index.htm accessed 28 September 2019.

${ }^{15}$ http://www.ilo.org/global/standards/introduction-to-international-labour-standards/the-benefits-o f-international-labour-standards/lang--en/index.htm accessed 28 September 2019.

${ }^{16}$ Article 19 of the ILO Constitution.

${ }^{17}$ Ibid.

${ }^{18}$ Since 1950 ILO Codes of Practice have set out practical guidelines for public authorities, employers, workers, enterprises, and specialized occupational safety and health protection bodies. While they are not legally binding instruments and are not intended to replace the provisions of national laws, regulations, or accepted standards, the Codes of Practice provide valuable guidance on safety and health at work in certain economic sectors. See ILO Foreign Right Catalogue 2012. 
The Universalist perception of work and working relations is linked to a tradition of solidarity and commitment. ${ }^{19}$ Workers' right to freedom of association and, invariably, the right to take collective action lie at the core of all human rights because they arguably create the means by which all other rights are asserted and defended (Olowu, 2006: p. 129, 148). Since the Second World War, the ILO's primary efforts have been in the field of human rights protection and the guarantee of individual freedoms. As such, the ILO is the leader in developing that portion of international law dealing with the concept of human rights. More specifically, the ILO has developed world-wide mechanisms rather than the more limited type of regional protection (Gormley, 1996: p. 13-51).

Similarly, after the Second World War, the ILS have focused on human rights and more technical issues (Chigara, 2007: p. 706, 726). A number of ILS clauses go beyond the traditional field of labour law and touch upon matters of civil liberties (freedom of association), penal law (forced labour), and property law (indigenous people).The ILS are divided into 20 subjects that cover all aspects of labour relations ${ }^{20}$ including freedom of association and collective bargaining, equality at work, forced labour, child labour, tripartite consultation, labour administration, labour inspection, employment policy and promotion, vocational guidance and training, employment security, wages, working time, occupational safety and health at work, social security, maternity protection, migrant workers, seafarers and fishers, dock workers, indigenous and tribal peoples, and other special categories of workers.

Noteworthy, the notion of rights emerged as a consequence of the civil and political rights proclaimed by the French Declaration of the Rights of Man and of the Citizen of 1789, which stated that "men are born and remain free and equal in rights" and "any society in which no provision is made for guaranteeing rights has no Constitution." ${ }^{21}$

However, Charles Fourier ${ }^{22}$ is the father of the expression "the right to work." According to him, politics extol the rights of man and do not guarantee the prime and only useful right, which is "the right to work". As Mayer observes, such concerns are implicit in the two basic texts of the ILO, the Constitution of 1919 and the 1944 Declaration of Philadelphia. The first declares in its Preamble that the prevention of unemployment is one of the ways of improving "conditions of labour ... involving such injustice, hardship and deprivation to large numbers of people as to produce unrest so great that the peace and harmony of the world are imperilled" (Mayer, 1995: p. 225, 242).

The second, which concerns the aims and purposes of the organisation itself

${ }^{19}$ Amartya Sen, "Work and Rights" (2000) 139 International Labour Review 119, 128.

${ }^{20}$ ILO, Guide to International Labour Standards (ILO, Geneva 2008). Documents available at: http://www.ilo.org/wcmsp5/groups/public/---ed_norm/normes/documents/publication/wcms_0862 23.pdf accessed 28 September 2019.

${ }^{21}$ http://www.conseil-constitutionnel.fr/conseil-constitutionnel/root/bank_mm/anglais/cst2.pdf accessed 28 September 2019.

${ }^{22}$ Charles Fourier (1772-1837) was a French social theorist who advocated a reconstruction of society based on communal association of producers known as phalanges (phalanxes). His system came to be known as Fourrierism. 
and which is annexed to the Constitution, states in particular that all human beings, irrespective of race, creed, or sex, have the right to pursue both their material well-being and their spiritual development in conditions of freedom and dignity, economic security, and equal opportunity, and recognises the solemn obligation of the ILO to further among the nations of the world programmes which will achieve: 1) full employment and the raising of living standards; 2) the employment of workers in the occupations in which they can have the satisfaction of giving the fullest measure of their skill and attainments and make their greatest contribution to the common well-being.

Furthermore, the Declaration Concerning the Aims and Purposes of the ILO emphasises that all human beings "have the right to pursue both their material well-being and their spiritual development in conditions of freedom and dignity, of economic security and equal opportunity." 23 The ILO's legitimacy particularly after the adoption of the Declaration of Philadelphia (1944) depended on the promotion of human security for both metropolitan and native indigenous colonial labours (Chigara, 2010: p. 85). The right to work is recognised as a fundamental human right and is confirmed in the International Covenant on Economic, Social and Cultural Rights (CESCR) ${ }^{24}$ Articles 6 and 7 of the Covenant provide the following rights:

1) Right to freely chosen work, Right to gain a living by work;

2) Right to technical and vocational guidance and training;

3) Right to full and productive employment;

4) Right to conditions of political and economic freedoms;

5) Right to fair wages;

6) Right to equal remuneration for work of equal value;

7) Right of women to conditions not inferior of those of men.

The most significant concept devised by the ILO had an elevating effect on workers' rights in the new global context. The concerns in regard to guaranteeing and protecting workers' rights has become less challenging after decades of effective regulations and consensus among ILO member states. ILO Director-General Juan Somavia introduced the concept of "decent work" in 1999, shortly after assuming his position. The word "work" is intended to be broader than formal employment or labour, reflecting the variety of ways in which people contribute to the economy and society. ${ }^{25}$ The word "decent" insists that work ${ }^{23}$ The General Conference of the ILO in its $26^{\text {th }}$ Session in Philadelphia, adopted a The Declaration of Philadelphia on 10 May 1944. It is concerned with the aims and purposes of the International Labour Organisation and the principles which should inspire the policy of its member states. See documents at:

http://www.ilo.org/dyn/normlex/en/f?p=1000:62:0::NO:62:P62_LIST_ENTRIE_ID:2453907:NO\#dec laration accessed 28 September 2019.

${ }^{24}$ The International Covenant on Economic, Social and Cultural Rights (CESCR) was adopted with UN General Assembly resolution 2200A (XXI) of 16 December 1966. It entered into force on 3 January 1976 in accordance with Article 27. See documents at United Nations, Treaty Series, vol. 993, p. 3. Accessed 28 September 2014.

${ }^{25}$ The concept of "decent work" was seen by Juan Somavia as a strategic way of framing ILO objectives in that the term encompassed the needs of workers and developing countries without alienating employers and industrialized nations. See Gerry Rodgers et al. The International Labour Organization and the Quest for Social Justice, 1919-2009 (ILO, Geneva 2010) 223, 224. 
must be of acceptable quality in terms of income, working conditions, job security, and rights. ${ }^{26}$ The 2008 Declaration on Social Justice for a Fair Globalization recognises the "four equally important strategic objectives" of the Somavia's Decent Work Agenda: 1) promoting employment, 2) enhancing social protection, 3) promoting social dialogue, and 4) realizing rights at work. ${ }^{27}$

The Declaration further recognises that these four pillars are "inseparable, interrelated and mutually supportive." ${ }^{28}$ It is worth noting that the ILO's core labour standards, which spell out the right to decent working conditions, come under the category of the second generation of human rights. ${ }^{29}$

In the context of decent work, this holistic approach demands consideration of all human rights, not just those work rights that appear most relevant initially. For example, to combat child labour, policymakers must consider a minimum age for employment and the child's right to education, right to health, right to family life, and right to participation in the community, among other rights that may be affected by any policy changes (Macnaughton \& Frey, 2011: p. 441). To be relevant, the concept of decent work must go beyond the ILO's four Core Labour Standards embodied in the Decent Work Agenda. The definition of decent work must address whole jobs, whole people, and whole families. For the ILO to take the lead in this mission, it must recognize that the various dimensions of people's lives are interrelated, interdependent, and indivisible, and consequently must be addressed in a holistic human rights framework. ${ }^{30}$ These core values are central to the ILO's work to promote social justice and guarantee peace.

The holistic human rights approach encompasses the principles expressed in the ILO Declaration of Philadelphia and the ILO Declaration on Social Justice, including the principles that civil and political rights such as freedom of expression and association are essential to sustain progress, and that the "war against want" requires both national and international efforts to promote the common welfare. ${ }^{31}$ This approach by the ILO rests upon the idea that all human rights are equally inherent to human dignity, ${ }^{32}$ and accordingly cannot be ranked in a hierarchical order. The equal status of rights was also reaffirmed in the $1993 \mathrm{Vi}$ enna Declaration, which urged the international community and national gov${ }^{26}$ ibid.

${ }^{27}$ Declaration on Social Justice for a Fair Globalization, Para. I.A.

${ }^{28}$ Ibid. Para. I.B.

${ }^{29}$ The second generation of human rights are social, economic, and cultural rights. The right to work, to education, and to equal pay for equal work are rights of entitlement or "claim rights" that require active policies by the state. However, the individual citizen cannot take an action against the state if, for example, he or she should become unemployed or is unable to participate in the nation's cultural life. ${ }^{30}$ ibid.

${ }^{31}$ Philadelphia Declaration, $\$$ I; Declaration on Social Justice for a Fair Globalization.

${ }^{32}$ The Human Rights Based Approach to Development Cooperation towards a Common Understanding among UN Agencies at

https://undg.org/document/the-human-rights-based-approach-to-development-cooperation-toward s-a-common-understanding-among-un-agencies/ accessed 28 September 2014. This document of the United Nations Development Group (UNDG) proclaims the indivisibility of civil, cultural, economic, political, and social rights because all are inherent in the dignity of every person and therefore hold equal status. 
ernments alike to treat all human rights "in a fair and equal manner." 33

The prevailing argument here is that the ILO has already accomplished the greatest practical results at the universal level of any political institution in human history in the specialised area of human rights protection as it relates to trade union freedom. Winning the Nobel Prize in 1969 is testimonial of the ILO's accomplishments in its 50 years of existence. ${ }^{34}$ More than 40 years after the distinction, the ILO accomplishment in labour and human rights protection cannot be denied. In other words, it should be underscored that the ILO has broadened the traditional concept of human rights contained in international law by effecting the recognition of social, economic, property, and labour guarantees as an essential facet of any industrialised society. Human rights, such as life and liberty, are meaningless without a corresponding protection of labour standards in the new globalised context. This explains the fact that, following the adoption of the ILO Declaration on Fundamental Principles and Rights at Work in June 1998 an international consensus has emerged on the sanctity of ILO's core labour standards as a focal response to the imbalances of globalisation processes (Olowu, 2006: p. 129, 148).

Undoubtedly, human rights promote development, a view consistently held and voiced by the ILO since its inception (Wieczorek-Zeul, 2008: p. 249). The concept of development is the focus of developed countries and developing countries alike. The ILO is focused on effective and sustained development of its member states so that the ideals of social justice and peace re more likely to be achieved in a truly and fully developed environment. From that perspective, the ILO adheres to the idea that the rights at work can be broadly integrated within the same overall framework that also demands opportunities for women and men to obtain decent and productive working conditions of freedom, equity, security, and human dignity (Lafond, 2011: p. 3, 4).

The comprehensive view of society that informs the approach adopted in the ILO vision of decent work (ILO, 1999) provides a more promising understanding of the needs of institutions and policies in pursuit of the rights and interests of working people (Sen, 2000: p. 119, 128). The ILO, therefore, is the custodian of workers' rights within the United Nations system. ${ }^{35}$ In that role, the ILO seeks to protect both workers' rights and trade union interests. It transpires from ILO's Right to Organise and Collective Bargaining Convection, 1949 (No. 98) that, the basic human right to join a trade union and through the union to bargain for a fair return for one's labour is a foundation stone for constructive competition in the world market.

${ }^{33}$ Declaration on the Right to Development, G.A. Res. 41/128, art.6, U.N. Doe. A/RES/41/128 (Dec. 4 , 1986) (affirming the indivisibility and interdependence of all human rights); World Conference on Human Rights, June 14-25, 1993, Vienna Declaration and Programme of Action, T 5, U.N. Doc. A/CONF.157/23 (July 12, 1993) which proclaims that "all human rights are universal, indivisible and interdependent and interrelated."

${ }^{34}$ See Nobel Prize 1969: The International Labour Organization, available at http://www.nobelprize.org/nobel_prizes/peace/laureates/1969/, accessed 1 October 2019.

${ }^{35}$ ibid. 


\section{Ascertaining the Legitimacy of the ILO as a Standards Setting Organisation}

The legitimacy of the ILO as a standards setting organisation is undisputable. The ILO country members have willingly accepted its standards through the significance of signatures, ratifications and domestication of Conventions. ILO has the merit of being justified in its standards-setting role because it has consistently adopted a flexible, more updated approach to human rights. As the underlying philosophy in its approach is the promotion of social justice, all the International Labour Standards are rights based Conventions. As Gormley rightly puts it, the inescapable conclusion remains that the ILS represent a major advancement over the work of the League of Nations because the purpose of the League was to maintain the peace rather than to promote social justice and human rights (Gormley, 1966: p. 13-51). In fact, under the League system only the ILO had any major degree of competence to seek such idealistic goals. Indeed, the Philadelphia Declaration of 1944 set forth the philosophy of the ILO after World War II, which carried forward the work it had begun while under the League. Eventually, the Philadelphia Declaration was incorporated into the Constitution (Gormley, 1966: p. 13-51).

We must therefore agree with Gormley that the ILO has led the way in developing a new and more realistic definition of human rights by incorporating human, economic, and social rights into its numerous conventions. Even though single individuals cannot petition the ILO directly, as they can the Council of Europe's Commission of Human Rights cases can be presented by "an industrial association of employees or workers" under the text of Article 24 of the ILO Constitution. Accordingly, injured persons and labour groups can obtain some redress of their grievances in those instances wherein alleged violations of ILO conventions have occurred. Additionally, the ILO has developed the most advanced system of conflict-resolving global machinery available to both private actors and member states. Furthermore, even the International Court of Justice can be invoked in appropriate circumstances. In other words; labour groups have emerged as subjects of ILO "common law" (Gormley, 1966: p. 13-51). However, Wieczorek-Zeul writes that:

And yet, policy dialogue is not always easy. The governments of some of the countries we work with maintain that certain political or civil human rights conflict with their culture; other governments view women's rights and their right to sexual autonomy as not in keeping with their cultural values. There can, however, be no compromising on these issues. Women's rights, like any other human freedom, are non-negotiable. As a development policy maker, I can add that if these rights are not upheld, poverty reduction measures will only be half as effective (Wieczorek-Zeul, 2008: p. 249).

Despite Wieczorek-Zeul's sobering acknowledgement of the real challenges that exist, it must be emphasised that the ILO'S approach to human rights is actually broadly accepted by many developing countries. The International Labour 
Standards have influenced regional labour standards mightily in terms of setting labour rights. The strongest basis for labour rights in Africa lies in the African Charter on Human and Peoples' Rights, 1981 (the African Charter). Being the most widely accepted human rights instrument among African states, the Charter's potential as a tool for advancing worker's interests in Africa are enormous (Olowu, 2006: p. 129, 148). Article 10 of the African Charter guarantees the right to freedom of association; ${ }^{36}$ Article 11 provides for the right to freedom of assembly; ${ }^{37}$ and Article 15 secures the right to work under equitable and satisfactory conditions and to equality in wages. ${ }^{38}$

\section{The ILO's Holistic Approach to Combating Child Labour}

The ILO's approach to human rights in general and children's rights in particular is clear. Although some critics (see Waugh, 1982: p. 186) have underestimated the organisation's role in the promotion of human rights, the core of its action cannot be dissociated with the betterment of humanity in the work environment. Waugh writes that "The ILO has regarded human rights as encompassing whatever rights are essential to the betterment of human life. Looking to the basic needs of man, it has proposed programs for full employment, just, and favourable conditions of work and such regulations as well assure freedom and human dignity" (Waugh, 1982: p. 186). This is significant in that the ILO from its inception has promoted the protection of children. Two of the first six Conventions promulgated in 1919 were concerned with regulating the employment of children. ${ }^{39}$

In the pursuit of children's rights protection, the ILO's Convention 182 demands the elimination of the worst forms of child labour, and it is the most egregious cases that are most prone to be described as children's rights violations. A variety of rights are systematically violated in the process of carrying out any work deemed the "worst form of child labour." Article 3 (d) of Convention 182 forbids "work which, by its nature or the circumstances in which it is carried out, is likely to harm the health, safety or morals of children." ${ }^{40}$ Children's rights were carefully considered, even in earlier Conventions. In exploring the possibility of employment for young persons aged 13 to 15, the ILO urges the competent authorities to permit only work that is not likely to be harmful to their health or development and work that will not prejudice their attendance at school. ${ }^{41}$

\footnotetext{
${ }^{36}$ Article $10-1$. Every individual shall have the right to free association provided that he abides by the law. 2. Subject to the obligation of solidarity provided for in 29 no one may be compelled to join an association.

${ }^{37}$ Article 11 - Every individual shall have the right to assemble freely with others. The exercise of this right shall be subject only to necessary restrictions provided for by law in particular those enacted in the interest of national security, the safety, health, ethics and rights and freedoms of others.

${ }^{38}$ Article 15 - Every individual shall have the right to work under equitable and satisfactory conditions, and shall receive equal pay for equal work.

${ }^{39}$ See ILO Minimum Age (Industry) Convention, 1919 (No. 5) and ILO Night Work of Young Persons (Industry) Convention, 1919 (No. 6).

${ }^{40}$ Article 3(d) Worst Forms of Child Labour Convention, 1999 (No. 182).

${ }^{41}$ See Article 7 (1a) (1b) Minimum Age Convention, 1973 (No. 138).
} 
Smolin rightly observes that "although the ILO has been adopting Conventions relating to child labour since its inception in 1919, its activism in regard to child labour has passed through four distinct stages." He notes that the first stage ran from 1919 and 1932, when the ILO created five area-specific Minimum Age Conventions in Industry (1919), Sea (1920), Agriculture (1921), Trimmers and Stocker (1921), and Non-Industrial Employment (1932). However, he observes that the ILO's Constitution and these five initial conventions failed to declare the abolition of child labour as a goal or purpose, or even use the term "child labour" (Smolin, 2000: p. 942, 987).

In regard to the second stage, Smolin reports that the ILO's activism on child labour primarily involved creating a revised version of the Minimum Age Sea (1936), Industry (1937), and Non-Industrial Employment (1937) Conventions; they raised the benchmark minimum age for full-time employment from fourteen to fifteen. Most significantly, unlike the conventions adopted in the first stage of activism, the term "children" was used in the second stage conventions to refer to persons under the age of fifteen or those still within compulsory education laws. He also observes that, in its initial two periods of activity on child labour, encompassing over fifty years, the ILO was concerned principally with establishing fourteen (and then later fifteen) as the basic minimum age for most forms of employment outside the family context (Smolin, 2000: p. 942, 987).

Most remarkably he observes that the terminology of "abolishing child labour" was absent from the Conventions of the second stage activism. Moreover, the ILO's foundational 1944 Philadelphia Declaration of Principles, which clarified the purposes of the ILO, failed to include the abolition of child labour within the core principles of the ILO, and referred to children only in the context of the provision for child welfare and maternity protection. As to the third stage of the ILO activism on child labour, he notes that the 1973 Minimum Age Convention (C 38) was intended to replace gradually the area-specific Conventions mentioned above. Finally, the purpose of the new Convention included the total abolition of child labour (Smolin, 2000: p. 942, 987).

From that perspective, there was not only a need to correlate compulsory education with minimum age employment standards, but also the necessity of choosing a floor of fifteen as the minimum age employment standard. Indeed in its purpose, scope, and standards, the 1973 Minimum Age Convention was ambitious compared to previous Conventions. However, given the fact that treaties are only binding on nations that ratify them, the mere existence of an ambitious Convention is meaningless unless the convention attracts a significant number of ratifications. Smolin concludes, therefore, that the major failing of the Minimum Age Convention from the ILO's perspective was likely its failure to attract sufficient ratifications, particularly among nations containing most of the world's child labourers (Smolin, 2000: p. 942, 987).

Smolin observes that the fourth stage of ILO activism on child labour began in the 1990s and continues today. The characteristics of this fourth stage include moving child labour from the periphery to the centre of the ILO's mission, using 
child labour as an exemplary of a broader effort to seek social justice in the context of trade liberalization and the dominance of economic neo-liberalism, implementing an extensive program of cooperative technical assistance with developing nations under the rubric of the International Programme on the Elimination of Child Labour (IPEC), prioritising goals through targeting the worst forms of child labour for time-bound programs, and moving the ILO into new areas not traditionally associated with the labour movement. ${ }^{42}$

It is evident that the ILO's approach to an effective action against child labour is based on the conviction that a clear national policy against the exploitation of children is the fundamental point of departure. The ILO admits that the special merit of a national policy lies in the fact that it articulates societal objectives and commitments and provides a coherent framework for an associated programme of action. Furthermore, a national policy and programme action on child labour should be placed in specific context of national, social, and economic development policies that address the larger issues of poverty, education, and development (See Thijs, 2000: p. 7).

The ILO has always stood for the effective abolition of child labour, and this objective is enshrined in a number of instruments. The ILO permanently and consistently advocates the development of national policy on child labour as a prerequisite for a successful campaign against the practice. In line with its objective, the ILO set up the IPEC.

IPEC was created in 1992 with the overall goal of the progressive elimination of child labour, to be achieved through strengthening the capacity of countries to deal with the problem and promoting a worldwide movement to combat child labour. It includes a technical cooperation programme that works towards the elimination of child labour by strengthening national capacities to address child labour problems and by contribution to the worldwide movement to combat child labour. IPEC currently has operations in 88 countries, with an annual expenditure on technical cooperation projects that reached over US\$61 million in 2008. It is the largest programme of its kind globally and the biggest single operational programme of the ILO. ${ }^{43}$ Notably, there has been a steadily-increasing number of governments who have signed a Memorandum of Understanding with the ILO, making clear their commitment to the elimination of child labour.

The ILO recognises the need to set priorities for actions against child labour; the most vulnerable groups must be the main priority. IPEC policy acknowledges that while the abolition of child labour is the ultimate goal, flagrant cases of child abuses require priority attention. At the $87^{\text {th }}$ session of the General Conference of the International Labour Conference, ILO member states adopted a new Convention authorising immediate action for the elimination of the worst

\footnotetext{
${ }^{42}$ In his analysis Smolin indicates that these new areas are criminal matters such as prostitution, pornography, and drug trafficking, and the question of minimum age limits for military service, through explicit inclusion of these matters in the 1999 Convention on the Worst Forms of Child Labour.

${ }^{43}$ See ILO, http://www.ilo.org/ipec/programme/lang--en/index.htm. Accessed 28 September 2019.
} 
forms of child labour. ${ }^{44}$

It is worth noting that national ILO offices work to reinforce the national tripartite relationship between the social partners of government, employers, and workers. Developed in 2010 and implemented in Ghana and the Ivory Coast, the ILO-IPEC project Towards child labour free cocoa-growing communities through an integrated area-based approach is one of the first projects designed to address the full range of child labour issues in cocoa-growing communities, as opposed to focusing simply on cocoa farming in isolation. ${ }^{45}$

The integrated and coordinated approaches adopted by the ILO manifest themselves through supporting the development of tailored Decent Work Country Programmes and National Action Plans to eliminate child labour. In West Africa this has included the strengthening of national legal frameworks concerning child labour and regional initiatives to combat child trafficking. The International Programme to Eliminate Child Labour, a joint ILO-IPEC effort, also funds community-level interventions that are implemented through social partners or national or international NGOs. At the international level the same tripartite structure brings together governments with international employers' and workers' organisations concerned about child labour in the cocoa supply chain. ${ }^{46}$

The integrated area-based ethos approaches the elimination of child labour as a process embedded in wider national strategies for eliminating child labour, promoting education and decent work, and reducing poverty. The approach aims to create an environment where children do not simply shift from one hazardous sector or occupation to another, where vulnerable families and communities are empowered to address their economic situation (often a root cause of child labour), and where the necessary consensus at both community and national levels is generated to garner the support needed to effect long-term change.

The most recent and comprehensive ILO standards on child labour are the Minimum Age Convention, 1973 (No. 138) and its accompanying Recommendation (No. 146), and the Worst Forms of Child Labour Convention, 1999 (No. 182) and its accompanying Recommendation (No. 190). The ILO Bureau for Workers' Activities (ACTRAV) has been involved in issues concerning environmentally sustainable development and child labour for many years, through supporting trade unionists to develop and to implement their own policies and action plans. ${ }^{47}$ Assessing its success in combating the worst forms of child labour, the ILO has admitted that "the current pace of progress is too slow to reach the 2016 target to the elimination of worst forms of child labour" (See ILO, 2013: p. 13). However, the ILO regards the pace of progress from 2000 to ${ }^{44}$ Worst Forms of Child Labour Convention, 1999 (No. 182).

${ }^{45}$ See SWAC/OECD 2011. Document available at http://www.oecd.org/swac/publications/49069653.pdf, accessed 28 September 2019.

${ }^{46}$ ibid.

${ }^{47}$ ACTRAV's mission at http://www.ilo.org/actrav/about/lang--en/index.htm accessed 28 September 2019. 
2012 as "satisfactory" in terms of the elimination of worst forms of child labour. Although the pace may have slowed in recent years, the ILO and IPEC have made great strides in the struggle against child labour not only in the Ivory Coast but also around the globe.

\section{Conclusion}

The ILO thrives in addressing all labour issues across the globe. The ILO was one of the earliest multilateral organisations and the first permanent organisation to draft treaties on a regular basis (Charnovitz, 2000: p. 147, 184; Morellet, 1933: p. 46, 52). The ILO is devoted to promoting social justice and internationally-recognised human and labour rights, constantly pursuing its founding vision that labour peace is essential to prosperity. It is therefore admitted that ILO standards are fit for purpose. Since its establishment, the ILO has focused on improving human rights in the work environment. Moreover, its mechanisms, its adherence to social justice, universal values, and the relevance of its convention to contextual realities of most countries, have encouraged more members to adopt its standards through the signature, ratification and the domestication. In recent years, the ILO has placed greater emphasis on the fight against on child labour worldwide. This effort among other in the work environment has strengthened its standards-setting role and has demonstrated the weaknesses in arguments disputing the relevance of the organisation and its legitimacy.

\section{Conflicts of Interest}

The authors declare no conflicts of interest regarding the publication of this paper.

\section{References}

Beguin, B. (1959). ILO and the Tripartite System. International Conciliation, 32, 410, 448.

Charnovitz, S. (2000). The International Labour Organisation in its Second Century in Max Planck Yearbook of United Nations Law (Kluwer Law International, Netherlands), 147, 184.

Chigara, B. (2007). Latecomers to the ILO and the Authorship and Ownership of ILS. Human Rights Quarterly, 29, 706-726. https://doi.org/10.1353/hrq.2007.0026

Chigara, B. (2010). The ILO and "Human Security" of Sub-Saharan African Labour. In A. Abass (Ed.), Protecting Human Security in Africa (p. 85). Oxford: Oxford University Press.

Douglas W, A., Ferguson, J., \& Klett, E. (2004). An Effective Confluence of Forces in Support of Workers' Rights: ILO Standards, US Trade Laws, Unions, and NGOs'. Human Rights Quarterly, 26, 273, 299.

Etukudo, A. (1991). From Scepticism to Confidence: African Employers' Organizations as Partners in Development. International Labour Review, 130, 113.

Gormley, P. (1996). The Emerging Protection of Human Rights by the International Labour Organization. Albany Law Review, 30, 13-51.

Hansenne, M. (1994). Promoting Social Justice in the New Global Economy. Monthly Labour Review, 117, 3. 
Helfer, L. (2006). Understanding Change in International Organisations: Globalisation and Innovation in the ILO. Vanderbilt Law Review, 59, 649-726.

ILO (1954). Record of Proceedings, International Labour Conference, 37th Session, Geneva.

ILO (2008). Guide to International Labour Standards. Geneva: ILO. https://www.ilo.org/global/standards/information-resources-and-publications/publicat ions/WCMS_246944/lang--en/index.htm

ILO (2012). The Tripartite Process of Determining Hazardous Child Labour: Guide for Facilitators. Geneva: ILO.

ILO (2013). Making Progress against Child Labour: Global Estimates and Trends 2000-2012 (p. 13). Geneva: ILO.

ILO. International Labour Law. http://actrav.itcilo.org/actrav-english/telearn/global/ilo/law/lablaw.htm

Jancauskas, R. (1959). The Concept of Social Justice: Some Current Applications. Review of Social Economy, 17, 34-50. https://doi.org/10.1080/00346765900000003

Kuruvilla, S., \& Verma, A. (2006). International Labour Standards, Soft Regulation, and National Government Roles. Journal of Industrial Relations, 48, 41-58. https://doi.org/10.1177/0022185606059313

La Rosa, \& Duplessis, I. (2001). Tripartism within the ILO: A Special Case. International Training Centre, Turin 1.

Lafond, G. (2011). Dignity at Work: Why Is International Law Fit for the Job? Revue Quebecoise de Droit International, 24, 3-4.

Lorenz, E. (2002). Bringing Law to Globalization through ILO Conventions: A Labor Perspective on the Core Labor Standards, Michigan State University, Detroit College of Law's. Journal of International Law, 11, 101, 112.

Macnaughton, G., \& Frey, D. F. (2011). Decent Work for All: A Holistic Human Rights Approach. American University International Law Review, 26, 441.

Maupin, F. (2009). New Foundation or New Facade? The ILO and the 2008 Declaration on Social Justice for a Fair Globalization. European Journal of International Law, 20, $823,852$.

Mayer, J. (1995). The Concept of the Right to Work in International Standards and the Legislation of ILO Member States. International Labour Review, 124, 225, 242.

Meeker, R. (1923). The International Labour Organisation. ANNALS of the American Academy of Political and Social Science, 108, 206, 210.

Melanson, R. A. (1979). Human Rights and the American Withdrawal from the ILO. Universal Human Rights, 1, 43, 61.

Merret, C. D. (2004). Social Justice: What Is It? Why Teach It? Journal of Geography, 103, 93-101. https://doi.org/10.1080/00221340408978584

Morellet, J. (1933). Legal Competence of the International Labour Organisation. Annals of the American Academy of Political and Social Science, 166, 46-52. https://doi.org/10.1177/000271623316600108

Nghia P. T. (2010). Incorporating the Core International Labour Standards on Freedom of Association and Collective Bargaining into Vietnam's Legal System' (PhD. Thesis, Brunel University).

Nielsen, H. K. (1995). Supervisory Machinery of the International Labour Organisation. Nordic Journal of International Law, 64, 129, 150.

Olowu, D. (2006). Globalisation, Labour Rights, and Challenges for Trade Unionism in 
Africa. Sri Lanka Journal of International Law, 18.

Rodgers, G. et al. (2010). The International Labour Organization and the Quest for Social Justice, 1919-2009. Geneva: ILO.

Rubin, N., Kalula, E., \& Hepple, B. (2005). Code of International Labour Law: Volume 2, Principal Standards of International Labour Law, Part 1: Law, Practice and Jurisprudence. Cambridge: Cambridge University Press.

Sen, A. (2000). Work and Rights. International Labour Review, 139, 119-128. https://doi.org/10.1111/j.1564-913X.2000.tb00406.x

Simpson, W. R. (1994). The ILO and Tripartism: Some Reflections. Monthly Labour Review, 117, 40, 45 .

Smolin, D.M. (2000). Strategic Choices in the International Campaign against Child Labour. Human Rights Quarterly, 22, 942, 987.

Specht, L., Ratna, K., Balakrishnan, R., Chantal, T., \& Rubek, D. M. T. (2003). Theme I: Economy, Prosperity, and Social Justice. Leiden Journal of International Law, 16, 849-871. https://doi.org/10.1017/S0922156503001535

Stiglitz J. E. (2002). Employment, Social Justice and Societal Well-Being. International Labour Review, 141, 9, 29.

Thijs, G. (2000). National Policies and Programmes in Action against Child Labour (International Labour Office, Geneva).

Thomas, A. (1921). The International Labour Organisation, Its Origin, Development and Future. International Labour Review, 135, 261.

Valticos, N., \& Von Potobsky, G. (2005). International Labour Law (Kluwer Law and Taxation, Boston) 20.

Visser, G. (2001). Social Justice, Integrated Development Planning and Post-Apartheid Urban Reconstruction. Urban Studies, 38, 1673-1699. https://doi.org/10.1080/00420980120084813

Waugh, D. A. (1982). The ILO and Human Rights. Comparative Labour Law, 5.

Wieczorek-Zeul, H. (2008). Human Rights and Development. Environmental Policy and Law, 38, 249.

Wisskirchen, A. (2005). The Standard-Setting and Monitoring Activity of the ILO: Legal Questions and Practical Experience. International Labour Review, 144, 253-289. https://doi.org/10.1111/j.1564-913X.2005.tb00569.x 